\title{
INVESTIGATIONS INTO THE MECHANICAL PROPERTIES OF ALPINE SNOW-PACKS
}

\author{
By C. M. Keeler and W. F. Weeks \\ (U.S. Army Cold Regions Research and Engineering Laboratory, Hanover, \\ New Hampshire 03755, U.S.A.)
}

\begin{abstract}
Data on the physical properties of seasonal alpine snow have been collected from the Beartooth Mountains near Cooke City, Montana (elevation $\approx 3000 \mathrm{~m}$ ) and the Bridger Range near Bozeman, Montana (elevation $\approx 2200 \mathrm{~m}$ ). Systematic measurements of snow density, temperature, structure, ram and Canadian hardness, centrifugal tensile strength and shear strength measured with a shear box and several types of shear vanes are included. Test results were grouped according to gross snow types (cohesive fine-grained "winter" snow, depth hoar, new snow, etc.) and whether the snow was wet or dry. Then interrelations between the different test parameters were studied. A plot of ram number versus density for winter snow gave a log-linear relation similar to that suggested for polar snows. Both shear-vane and centrifugal-tensile results when plotted as a function of porosity are well described by the negative exponential relation suggested by Ballard and Feldt. Depth hoar and wet snow invariably have lower strength values at any given density. There is an excellent one-to-one agreement between values obtained with the shear vane and the shear box.

Several field experiments were performed to study the sources of error in making in-situ mechanical tests on snow without utilizing a pit wall. Statistical analysis of the results shows that the main factor contributing to the experimental scatter is lateral inhomogeneity in the snow cover. There was no significant difference between the results of different operators. The standard deviation of a group of strength tests is shown to be directly proportional to the mean value of the group. This indicates that a logarithmic transformation should be made in handling snow strength results in order to stabilize the variance. It is emphasized that the systematic relations between snow properties invariably become obscured when different snow "types" are indiscriminately grouped together.
\end{abstract}

RÉsumé. Investigations des propriétés mécaniques de couches de neige alpines. Des données sur les propriétés physiques de la neige saisonnière alpine ont été collectées dans les Beartooth Mountains près de Cooke City, Montana (altitude environ $3000 \mathrm{~m}$ ) et le Bridger Range près de Bozeman (Montana) (altitude environ $2200 \mathrm{~m})$. Des mesures systématiques de la neige: densité, température, structure, dureté de battage et canadienne, force de tension centrifuge et de cissaillement mesurée avec une boîte à cissaillement et plusieurs types de vannes de cissaillement, ont été ajoutées. Les résultats des mesures ont été groupés en types généraux de neige (neige d'hiver à grains fins, givre de profondeur, nouvelle neige, etc.) suivant que la neige était sèche ou humide. Puis les relations entre les différents paramètres ont été étudiés. Le report des nombres de battage en fonction de la densité pour la neige d'hiver donna une relation logarithmique-linéaire similaire à celle suggérée par la neige polaire. A la fois les résultats des mesures de cissaillement et tensions centrifuges, portés en fonction de la porosité, sont bien décrites par une relation exponentielle négative suggérée par Ballard et Feldt. Le givre de profondeur et la neige humide ont invariablement des cohésions plus faibles pour toute densité. Il y a un excellent accord pour chaque cas entre les valeurs obtenues par les vannes à cissaillement et la boîte à cissaillement.

Plusieurs expériences sur le terrain ont été réalisées pour étudier les sources d'erreur en effectuant des mesures mécaniques in situ de la neige sans utiliser le mur d'un puits. L'analyse statistique des résultats montre que le facteur principal contribuant à la dispersion expérimentale est l'imogénéité latérale dans la couverture de neige. Il n'y avait pas de différence significative entre les résultats des différents opérateurs. L'écart standard d'un groupe de mesures de cohésion était directement proportionnelle à la valeur moyenne du groupe. Cela indique qu'une transformation logarithmique devrait être faite dans l'exploitation des résultats des mesures de cohésion de la neige afin de stabiliser la variance. On insiste sur le fait que les relations systématiques entre les propriétés de la neige deviennent invariablement obscures lorsque différents
types de neige sont groupés sans discrimination.

Zusammenfassung. Untersuchungen über die mechanischen Eigenschaften von Schneelagen alpinen Typs. Daten über die physikalischen Eigenschaften alpinen Winterschnees wurden in den Beartooth Mountains nahe Cooke City, Montana (Höhe $3000 \mathrm{~m}$ ), und in der Bridger Range nahe Bozeman, Montana (Höhe $2200 \mathrm{~m}$ ), gewonnen. Sie schliessen systematische Messungen der Schneedichte, Temperatur, Struktur, des Rammwiderstandes, der zentrifugalen Dehnungsfestigkeit und Scherfestigkeit ein, die mit einer Scherschachtel und einigen Typen von Scherflügeln durchgeführt wurden. Die Testergebnisse wurden in Gruppen entsprechend den Grundschneearten (zusammenhängender feinkörniger Winterschnee, Tiefen-Reif, Neuschnee etc.) und der Durchfeuchtung des Schnees zusammengestellt. Dann wurden die gegenseitigen Beziehungen zwischen den verschiedenen Testparametern untersucht. Eine Aufzeichnung der Rammzahl in Abhängigkeit von der Dichte für Winterschnee ergab eine log-lineare Beziehung ähnlich der für Polarschnee vorgeschlagenen. Die Darstellung sowohl der Scherung als auch der Zentrifugaldehnung in Funktion der Porosität wird gut durch die negative Exponentialbeziehung beschrieben, die Ballard und Feldt vorgeschlagen haben. Tiefenreif und feuchter Schnee haben bei jeder gegebenen Dichte niedrigere Festigkeitswerte. Zwischen den Werten, die mit den Scherflügeln und der Scherschachtel gewonnen wurden, besteht eine ausgezeichnete Übereinstimmung. 
Einige Feldversuche wurden unternommen, um die Fehlerquellen zu studieren, die bei mechanischen Versuchen in situ ohne Benutzung einer Schachtwand auftreten. Statistische Analysen der Ergebnisse zeigen, dass die seitliche Inhomogenität der Schneedecke die Hauptursache für die Streuung der Ergebnisse ist. Es gab keine bedeutenden Unterschiede zwischen den Ergebnissen verschiedener Beobachter. Der mittlere Fehler einer Gruppe von Festigkeitsprüfungen erweist sich als direkt proportional zum Mittelwert der Gruppe. Dies legt nahe, eine ln-Transformation bei der Bearbeitung von Schneefestigkeitsmessungen zur Stabilisierung der Varianz anzuwenden. Es wird nachdrücklich darauf hingewiesen, dass die systematischen Beziehungen der Schneeigenschaften unvermeidlich verschleiert werden, wenn verschiedene Schneearten unterschiedslos zusammengruppiert werden.

\section{INTRODUCTION}

During and since the I.G.Y., considerable information has been obtained concerning the mechanical properties of perennial dense polar snow. It was hoped that the present project would be able to extend these studies into the low-density range $\left(<0.350 \mathrm{~g} / \mathrm{cm}^{3}\right)$ using, when possible, tests identical to those used on polar snow. Because a wide lateral variation in snow depths and presumably physical properties was expected, attention was focused on tests using apparatus that was reasonably portable or could readily be made so. It was then planned to establish as many interrelations as possible between the parameters measured by these tests. This would facilitate the rapid characterization of a given snow-pack for any specific purpose by a minimum number of hopefully simple tests.

During the months of April and May i964 and 1965, field studies were undertaken ig km north of Cooke City, Montana, in the cirque basin occupied by Goose Lake. The area of the cirque is roughly $2.5 \mathrm{~km}^{2}$ and a considerable portion of its floor exhibits a gently rolling relief ideal for snow studies. The general elevation of the cirque floor is $3000 \mathrm{~m}$, placing the research site just above the tree line. A detailed description of the Goose Lake area is given by Alford and Weeks (1965).

Because Goose Lake basin has rarely been visited during the winter, little was known about its snow conditions. Based on the observations reported in this paper, 2.4 to $3 \mathrm{~m}$ is probably a reasonable estimate of the maximum depth of snow on the ground during an average winter. Snow accumulation usually starts in late October or early November and the pack does not become isothermal until early May. The weather systems supplying snow to the area come from the west and there is a pronounced orographic effect on the accumulation between Cooke City $(2330 \mathrm{~m}$ ) and Goose Lake (Fig. I). Although Goose Lake proved to be an excellent location for snow studies, it was abandoned at the end of the 1965 field season because of the logistic difficulties in keeping it supplied during the winter.

The research program was continued during the winter of i $965-66$ at Bridger Bowl, Montana, a small ski area located approximately $32 \mathrm{~km}$ north-east of Bozeman, Montana, which has been instrumented for research by the Montana State University at Bozeman.

The Bridger Range is a long steep ridge which runs north-south. The ridge crest is generally $2400 \mathrm{~m}$ in elevation and rises approximately $760 \mathrm{~m}$ above the surrounding country. The weather systems which supply snow to this area come from the west and north-west. Because of the abrupt rise of the range, snow accumulation is a pronounced function of elevation (Fig. I). Although there are no long records of snow accumulation for the Bridger Bowl area, one can probably expect from $\mathrm{I} .5$ to $2 \mathrm{~m}$ of snow on the ground at the ski area in February and March. The snow is normally dry until April when it becomes isothermal at $0^{\circ} \mathrm{C}$.

\section{Previous Work}

The study of the properties of snow is a young discipline and the methodology has largely been adapted from other fields. Systematic measurements of the gross properties of a snow cover were first made by Seligman (I936) who was primarily interested in avalanche occurrence. Since that time the study of snow in situ via the "pit" method (i.e. the description of stratigraphy and the determination of density and temperature profiles) has been developed 


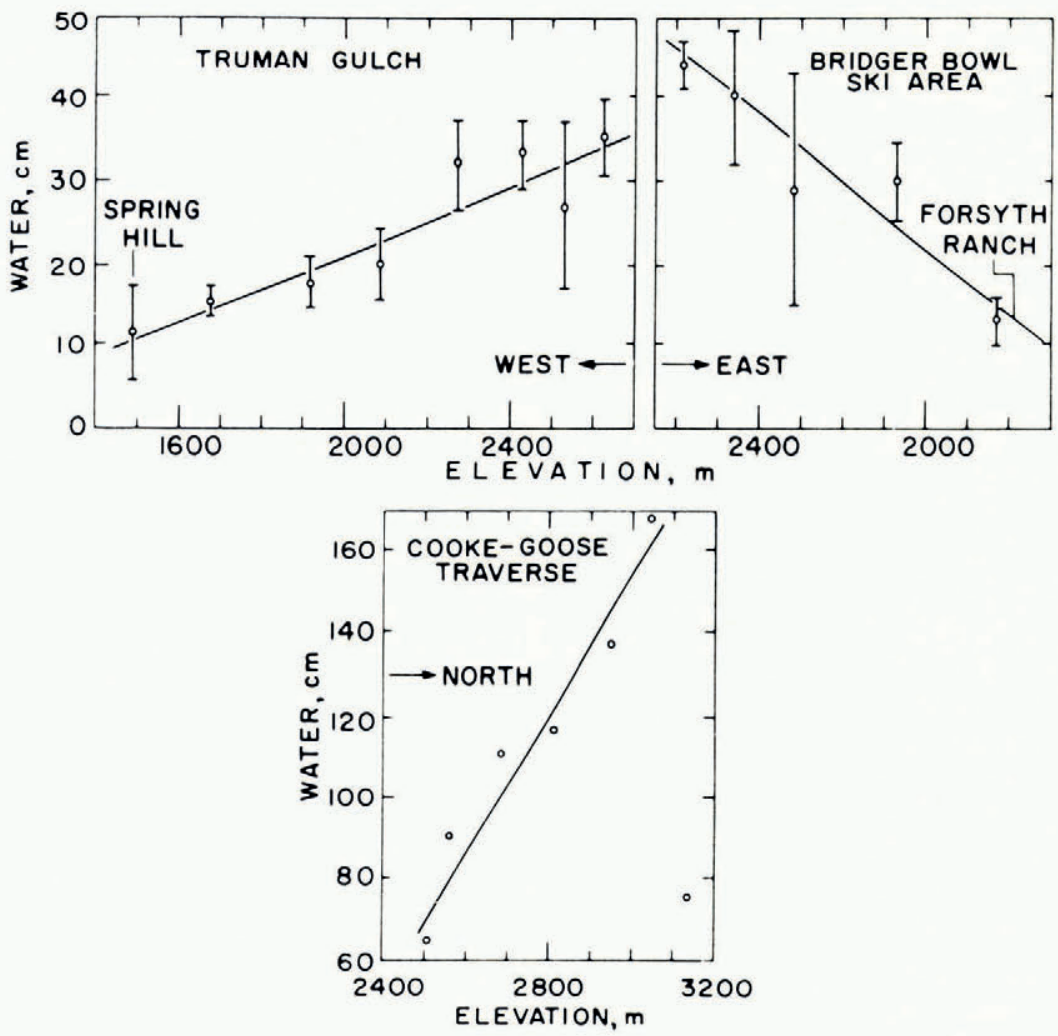

Fig. 1. Snow-pack water equivalent plotted against elevation. Goose Lake observations made on 30 April 1965, Bridger Bowl observations made on 15 March 1966

into a routine and is perhaps best described by Benson ( 1962 ). Pit studies have been used to study the broad regional variation of snow characteristics in Canada and the United States (Klein, 1949; Gold, I958; Williams and Gold, I958; Bilello, I957, 1967), in Russia (Rikhter, 1945; Formozov, 1946; Dmitriyeva, 1950), in Japan (Ishihari and Fukui, 1955), and in Switzerland (Bader and others, I939; see also the annual winter reports*). In the Rocky Mountain area of the United States detailed continuing programs of routine pit measurements including grain-size and ram-hardness profiles have been carried out at Alta, Utah (Atwater and others $\dagger$ ) and at Berthoud Pass, Colorado (Judson, I965).

Measurements of the strength properties of mountain snow have been much more sporadic, particularly those coupled with detailed pit observations. After the initial studies by the Swiss who first successfully adapted soil mechanics tests to low density snow (Bader and others, I939; Bucher, I948; de Quervain, I950) and the later studies by the Japanese using more refined techniques (Yosida and others, I955-58), strength studies have been made mainly on the higher density polar snows. The reasons for this emphasis are obvious: (a) most laboratory and field tests are much simpler to perform on the higher density snows $\left(>0.4 \mathrm{~g} / \mathrm{cm}^{3}\right)$ and (b) snows with densities less than $0.35 \mathrm{~g} / \mathrm{cm}^{3}$ are rare in the polar regions (Mellor, 1964) where most recent field studies have been concentrated as a result of the I.G.Y. emphasis on polar glaciology. Typical references to recent studies of the mechanical properties of high-density snows are Diamond (1956), Diamond and Hansen (1956), Butkovich (1956), Rula (196o),

* Winterberichte des Eidg. Institutes für Schnee- und Lawinenforschung (Weissfluhjoch, Davos), annually from 1935.

$\uparrow$ "Studies in avalanche control, Alta progress reports; informal reports to U.S. Forest Service", $1953-56$. 
Ramseier (1963) and Mellor and Smith (1966). Unfortunately many of the test procedures used by these investigators necessitate removing specimens from the snow-pack. Because of the extremely fragile nature of low-density snow and the high air temperatures and large amounts of incoming short-wave radiation encountered in temperate mountain regions, such tests are impractical. In addition many of the successful high-density tests become insensitive to physical property variations in the low-density range. This coupled with the naturally high variability in the characteristics of low-density snow has resulted in its mechanical properties being quite poorly understood.

\section{Nature of the SNow-Packs}

A characteristic of seasonal snow in mountainous areas is its extreme variability both during a given winter and between different winters. The three winters reported in this paper are no exception, showing pronounced differences in average density, thickness and depth-hoar development. To aid in the discussion of the strength data some representative pit data are included here (Fig. 2).

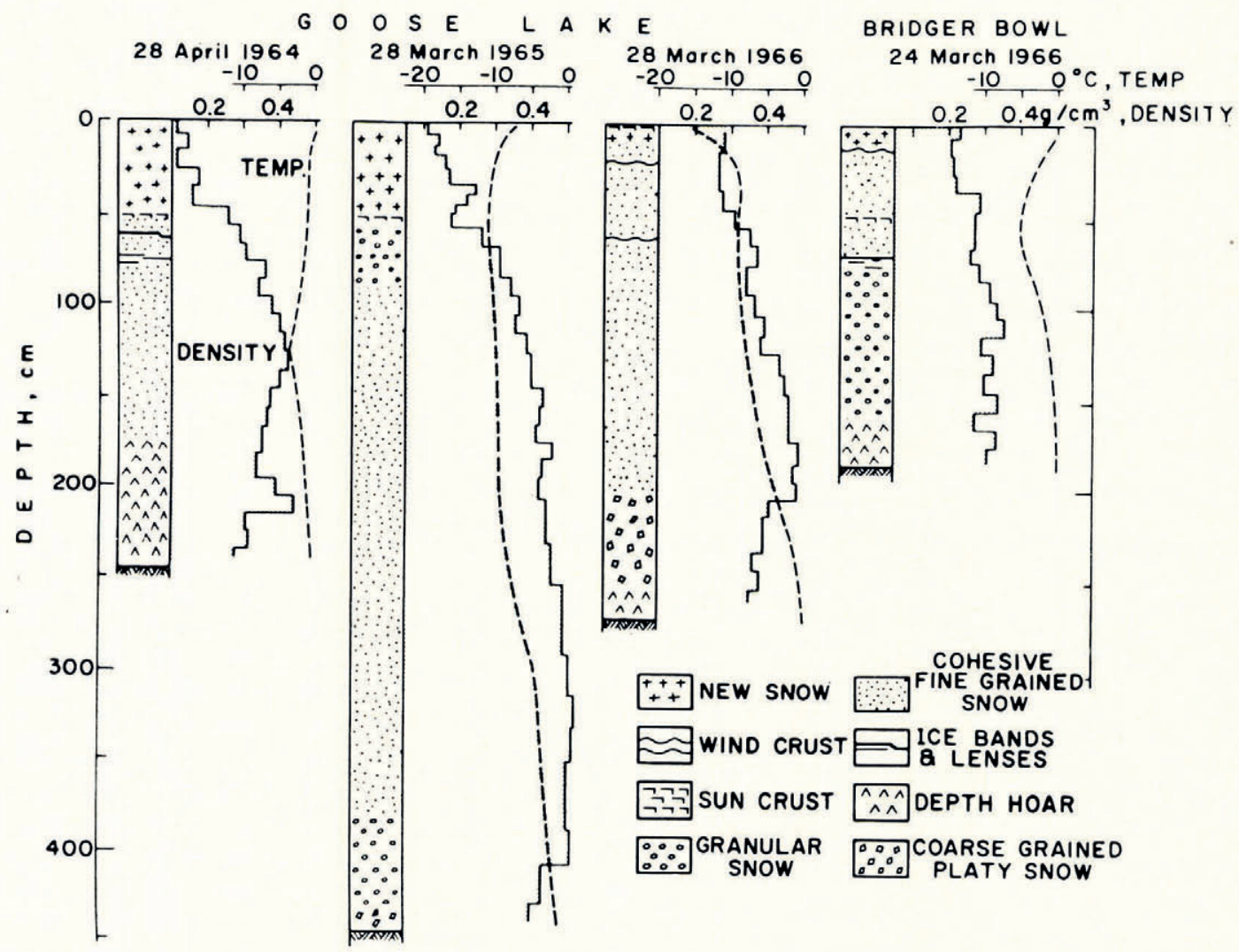

Fig. 2. Pit observations

Goose Lake, ${ }^{1964}$

The winter of $1963-64$, based on snow-course information from Silver Gate, Montana, appeared to be a near average snow year. Snow depths in the Goose Lake basin on 6 April varied between 2.3 and $3.5 \mathrm{~m}$ with an average value of roughly $2.6 \mathrm{~m}$. During the months of 
April and May when the pit observations were performed, three major stratigraphic units were distinguishable, both visibly and in the density and ram profiles. A layer of depth hoar roughly $0.7 \mathrm{~m}$ thick occurred at the bottom of the snow-pack. This thick layer of hoar was presumably produced by large temperature gradients in the snow during the cold early part of the winter when the pack was still quite thin. Although this depth hoar showed no visible layering, the ram and density profiles showed the presence of layers with slightly different physical properties. The depth-hoar layer gradually changed upward into a thick ( $1.0 \mathrm{~m}$ ) layer of uniform fine-grained snow showing a complete lack of either melt features or depthhoar development. This snow undoubtedly fell during the winter months when the air temperature was appreciably below $0^{\circ} \mathrm{C}$. Because the transition between the winter layer and depth hoar was gradational and difficult to fix visually, the boundary was usually located from the ram and shear-strength data. The top of this uniform layer was marked by a pronounced crust which formed during the few warm days preceding a storm on I I to I4 April. Above this crust was new snow which fell while the field site was occupied. This snow was characterized by wide variations in physical properties and contained several sun crusts. The most pronounced stratigraphic marker in this new snow was a colored layer apparently produced by large amounts of dust in the storm accumulation of 24 April.

These stratigraphic units were sufficiently pronounced to be identifiable for several days after the snow-pack became isothermal on 7 May. Fortunately the great majority of the strength measurements reported in this paper were determined prior to 7 May so that stratigraphic interpretation was not a major problem. After the snow-pack became isothermal, the gradual recrystallization and the ice lens formation produced mainly by percolating melt water gradually caused the earlier stratigraphy to become indeterminate.

Goose Lake, ${ }^{196} 6_{5}$

The winter of $1964-65$ was a heavy snow year in Goose Lake and the northern Rockies in general. The average snow accumulation at Goose Lake was considerably more than that of the previous year (Fig. 2). The snow started to accumulate early and a heavy snow-pack developed before extremely cold air temperatures were observed. For instance, it rained in December in Cooke City. There was, of course, no evidence of a rain crust in the pits at Goose Lake. This does, however, indicate that large amounts of snow were rapidly accumulating at Goose Lake at temperatures only slightly below freezing, effectively preventing the development of any significant depth hoar near the bottom of the pack. Instead a thick $(0.8 \mathrm{~m})$ layer of dense, medium grained ( 1.0 to $2.0 \mathrm{~mm}$ ) snow containing no pronounced stratigraphic markers was formed. This snow graded upward into $2.5 \mathrm{~m}$ of fine-grained dense homogeneous snow. Above this there was, in general, $\mathrm{I} m$ of relatively soft snow showing a few thin sun crusts.

Goose Lake, 1966

Goose Lake was visited on 28 March I 966 for the purpose of making comparative measurements. As was the case over much of the Rocky Mountain area, the first snowfalls of this winter were light and accompanied by cold temperatures which resulted in strong temperature gradients and the formation of a considerable layer of depth hoar. At Christmas time there was almost no snow at Cooke City (Dean Carter, personal communication) which is a highly unusual occurrence. The pit profile in Figure 2 is approximately two-thirds as deep and much less uniform than that of the previous year.

\section{Bridger Bowl, 1966}

The winter of 1966 was marked by low accumulation rates in the early season with the consequent formation of depth hoar. Heavy accumulation in February accompanied by relatively high temperatures caused the formation of numerous crusts. The pack went isothermal between late March and early April (depending on elevation). The extreme lateral 
variability of snow depth as a function of elevation over a small horizontal distance has been mentioned earlier (Fig. I). Even at a single elevation, for example, the $2000 \mathrm{~m}$ level, the snow depth varied from $\mathrm{I} .5$ to $2.5 \mathrm{~m}$ in a distance of $100 \mathrm{~m}$ due to wind effects.

\section{Results}

Almost all of the measurements of physical properties were performed either on the wall of a pit or in the snow a few meters from a pit. This procedure was adopted in an attempt to provide as much supplementary data as possible for the interpretation of the strength results. Snow temperatures ranged from $0^{\circ}$ to $-\mathrm{IO}^{\circ} \mathrm{C}$ with a mean of approximately $-4^{\circ} \mathrm{C}$. In the treatment of the data temperature effects have not been considered. Presumably most of the scatter remaining in the following curves is due to this fact. Roch (1966) has shown that temperature deviations of $5^{\circ} \mathrm{C}$ might be expected to produce strength changes of the order of $5^{\circ}$ per cent of the measured value for snow of a given density.

\section{Ram hardness}

The Rammsonde is a cone penetrometer which measures the "resistance to penetration" of a snow layer. A detailed description of the instrument is given by Haefeli (Bader and others, 1939). The ram profile is quite easy to measure even under adverse weather conditions and the technique has been used for years as a rapid means of characterizing a given snow-pack and locating depth-hoar layers in avalanche studies. Even though it has proved impossible to provide an exact physical interpretation of the meaning of the ram number (U. Nakaya, unpublished results), useful correlations have been obtained between the ram number and unconfined compressive strength (Abele, r963) and density (Bull, r956) for polar snows.

Figure 3 shows individual ram values obtained during 1964 and 1965 prior to the snowpack becoming isothermal, plotted against snow density measured at the same level in a

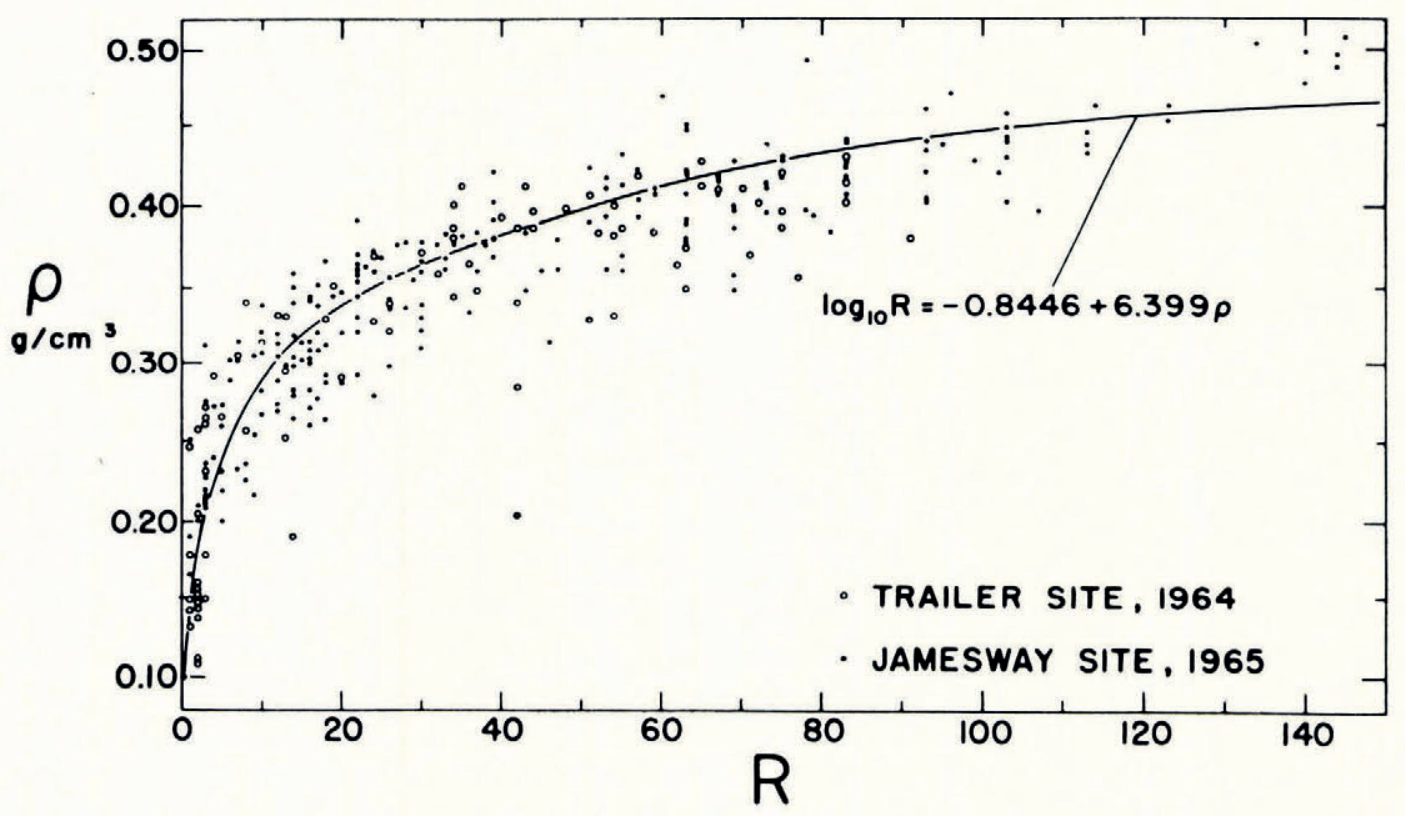

Fig. 3. Ram number plotled against dry-snow density (Goose Lake $1964-65$ ) 
nearby pit. Depth hoar is excluded from this figure. If for comparative purposes a relation similar to that used by Bull (1956)

$$
\log R=\alpha+\beta \rho
$$

is used to fit these data (403 points), one obtains by least squares $\hat{\alpha}=-0.8446$ and $\hat{\beta}=+6.399$ with a correlation coefficient $r=+0.94$ I. The 0.95 confidence limits on these estimates of $\alpha$ and $\beta$ are \pm 0.182 and \pm 0.519 respectively. These values are quite comparable to those $(\hat{\alpha}=-0.6 \mathrm{I} 07$ and $\hat{\beta}=+5.3 \mathrm{I} 06)$ obtained by Bull for a similar density range on the British North Greenland Expedition. It should be noted that in this type of plot considerable emphasis is given the lower ram values $(R<3 \mathrm{~kg})$. Unfortunately, the standard Rammsonde is not as sensitive to slight density changes in this low $R$ range as at higher values. Figure 4 a shows a similar plot for depth hoar which indicates the well-known fact that for snow of a given density, depth hoar gives lower ram values. This is quite reasonable in view of the pronounced decrease in cohesion associated with the development of depth hoar. It should be noted that the ability to discern the top of the depth hoar from the ram profile is more the result of the change in the ram number for a given density than it is due to basic density differences between hese two snow types.

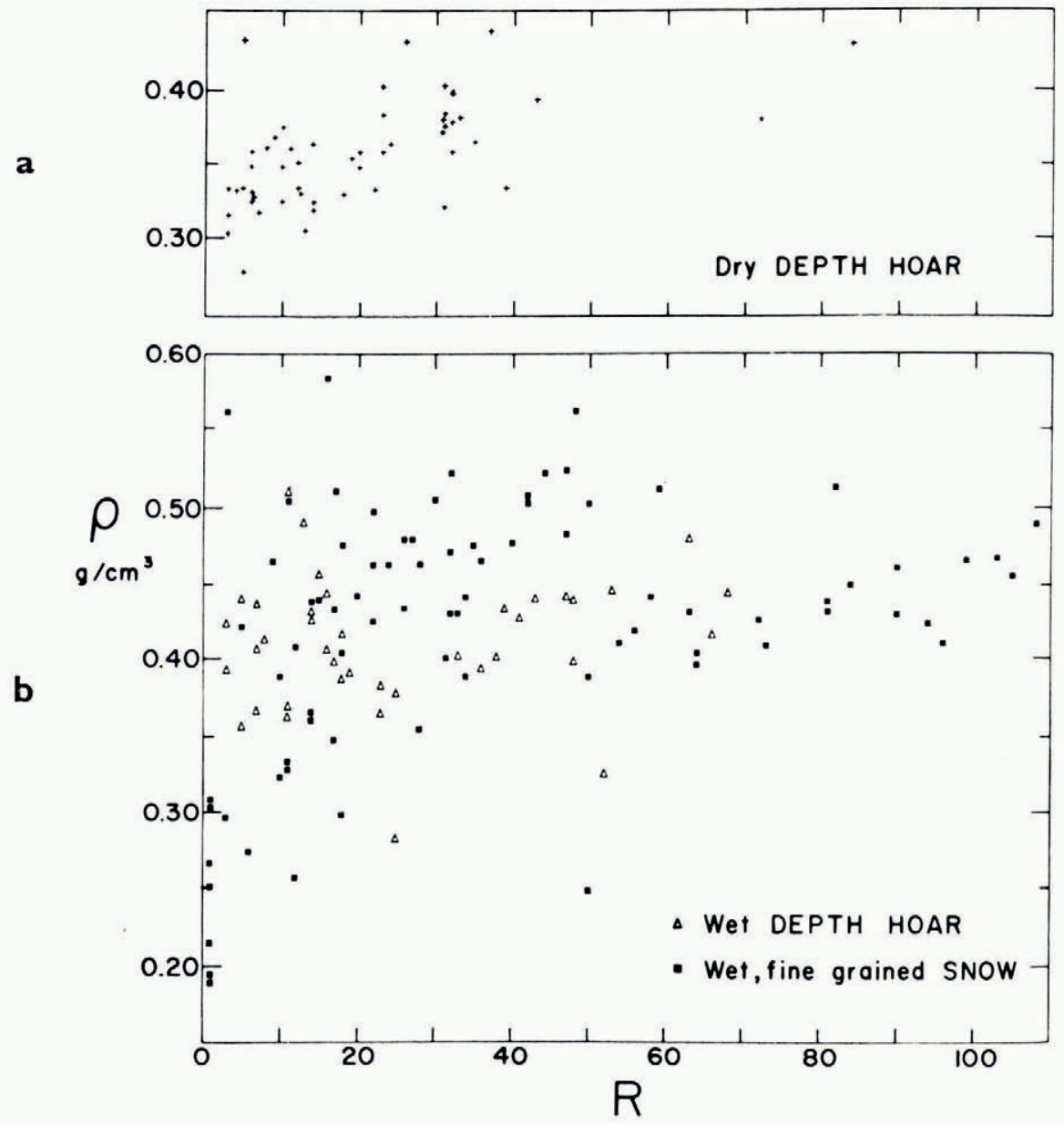

Fig. 4a. Ram number plotted against dry-depth-hoar density Fig. 4 b. Ram number plotted against wet-snow density 
Figure $4 \mathrm{~b}$ shows ram values obtained after the snow-pack had become isothermal and in some cases water-saturated. Although there is a pronounced increase in the scatter on this plot, it is evident that, in general, lower ram values occur for a given density compared with dry snow. There are probably at least two reasons for this. One is the result of conversion of a percentage of the ice to water. As long as this water is not lost in sampling, there would be no change in density. However, the reduction in the total volume of the solid would definitely reduce the ram number. The other reason is that the melting occurs in the region of the bonds between grains, reducing the overall cohesion of the snow. The increase in the scatter in the values from the later isothermal pits is undoubtedly the result of the formation of numerous irregularly spaced ice lenses and glands which may be present at a given level in a pit and absent a fraction of a meter away where the ram profile was determined.

\section{Centrifugal tensile strength}

The centrifugal tensile test is first mentioned in the literature by Haefeli (Bader and others, I939) and is more fully described by de Quervain (1950). The chief advantage of this test, in addition to its rapidity, is its ability to test very low-density snow. In our apparatus the sample was pushed from a standard $500 \mathrm{~cm}^{3}$ snow tube into a similar cylinder which is rotated about an axis normal to the axis of the cylinder. The sample is held in place by a twopronged clip which reduces the cross-sectional areas of the center of the sample. The speed of rotation of the cylinder is then increased until the snow sample fails and the revolutions per minute at the time of failure are read from a calibrated ammeter. The failure strength of the sample is determined by finding the force exerted on the cross-sectional area of the failure surface and integrating over the half-length of the cylinder. For the dimensions of the cylinder used, this reduces to

$$
\sigma_{\mathrm{t}}=\mathrm{I} . \mathrm{I} 66 \times \mathrm{IO}^{-9} M \mathcal{N}^{2}
$$

where $\sigma_{\mathrm{t}}$ is the failure strength $\left(\mathrm{kg} / \mathrm{cm}^{2}\right), M$ is the mass of the sample $(\mathrm{g})$ and $\mathcal{N}$ is the number of revolutions per minute at failure. A nomograph for determining values of $\sigma_{t}$ is given in Bader and others (I95I).

Figure 5 shows a plot of $\sigma_{t}$ versus porosity for dry fine-grained snow from both the I 964 and 1965 seasons. Because of the obvious "tail" in Figure 5 it was decided to fit the relation

$$
\frac{\sigma_{t}}{\sigma_{\mathrm{i}}}=\exp \left[-\frac{2 n}{\mathrm{I}-n}\right]
$$

where $\sigma_{\mathrm{i}}$ is the strength of fine-grained bubble-free ice with a random orientation and $n$ is the porosity. This relation is a theoretical one suggested by Ballard and Feldt (I966). Because $\sigma_{\mathrm{i}}$ is unknown, it was obtained by least squares by regressing $\sigma_{\mathrm{t}}$ on $\exp \left[-\frac{2 n}{\mathrm{I}-n}\right]$. The predicted value was 27.3 with a correlation of 0.867 . This is in remarkable agreement with the value of 28.3 extrapolated by Ballard and McGaw ( 1966 ) from Butkovich's ring-tensile data. This close agreement would indicate that the Goose Lake data could well be used as the low density continuation of Butkovich's data.

Figure 6 shows a similar plot containing $\sigma_{t}$ values for depth hoar. If Figures 5 and 6 are compared, it can be seen that the depth hoar has a lower $\sigma_{t}$ value for a given porosity. This is quite reasonable inasmuch as the formation of depth hoar is invariably associated with a decrease in cohesion.

It is interesting to compare the Montana $\sigma_{t}$ values with the results of similar tests from the literature. The Montana snow appears consistently stronger by a factor of 2 to 3 over the results of Bucher (I948) and de Quervain (1950). It is presently not possible to explain this discrepancy. It is encouraging to note that the present tests show far less scatter and a much simpler relation to density than previous tests by the centrifugal method (see Bader, i962, p. 36$)$. 
MECHANICAL PROPERTIES OF ALPINE SNOW-PACKS

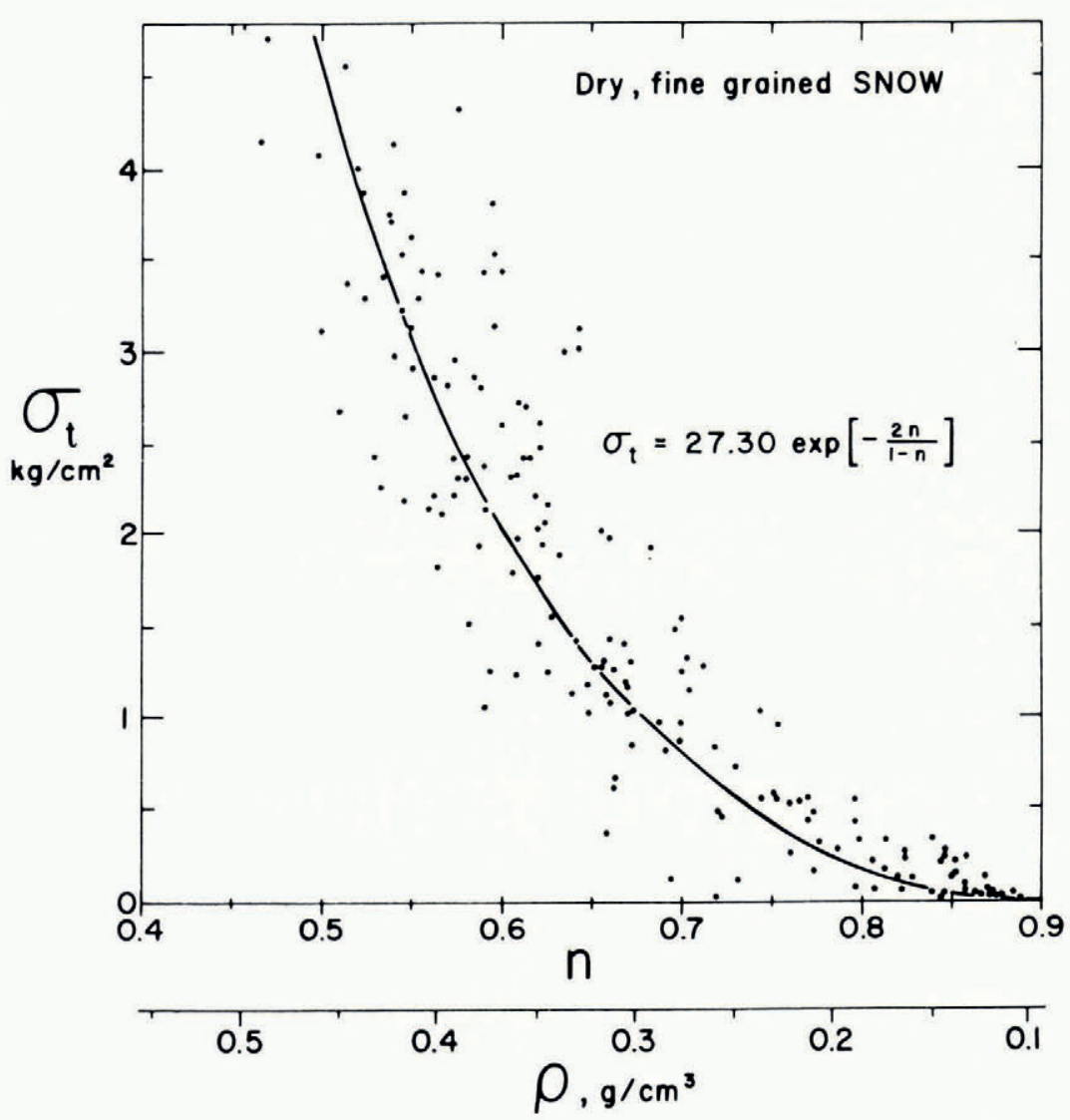

Fig. 5. Tensile strength plotted against porosity of dry, fine-grained snow (Goose Lake, 1964-65)

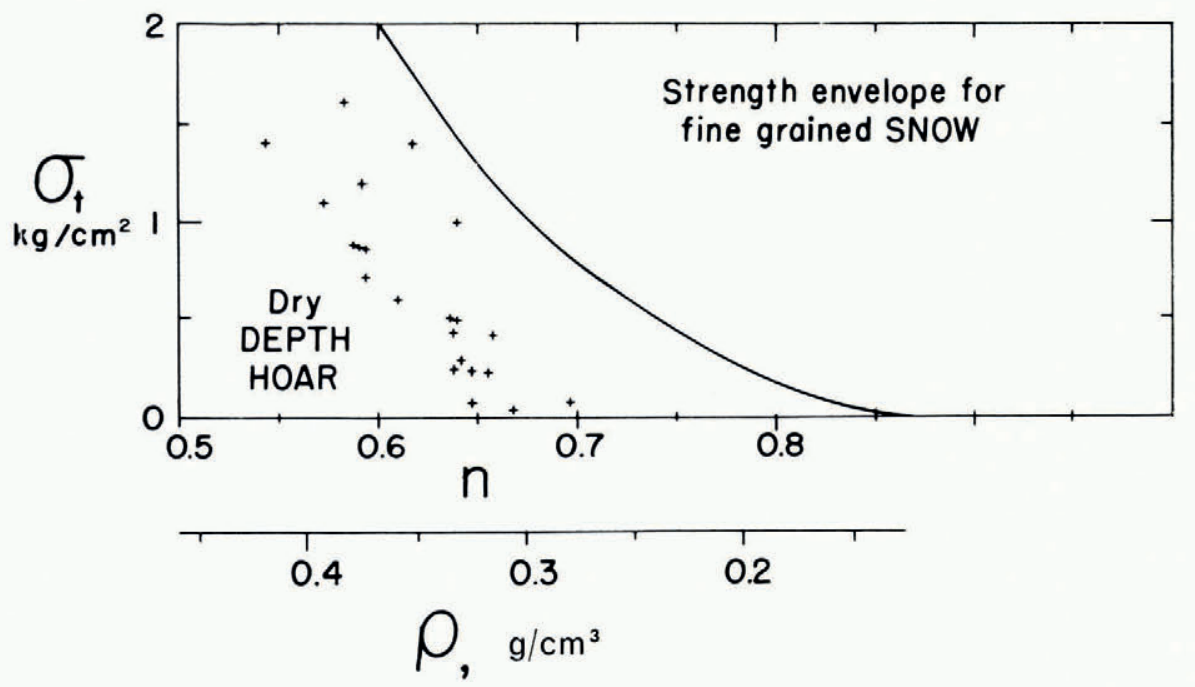

Fig. 6. Tensile strength plotted against porosity of depth hoar (Goose Lake, 1965) 


\section{Shear strength}

Shear box. Although the shear box has been mentioned in the literature for a number of years (de Quervain, I950), it is only recently that any appreciable number of measurements have become available (Roch, I966). The shear-box measurements are normally made parallel to the stratification by cutting a "step" in the wall of a pit. This prevents failure occurring over an area wider than the area of the shear box. The measurement of the force applied to the box at the time of failure was made with a Chatillon scale. Unfortunately the use of the shear box is limited to low densities and even at the lowest densities the failure surface was rarely planar.

Figure 7 shows the relationship between shear strength as determined using the shear box and porosity. It can be seen that the data extend only to porosities of about $0.6(\rho<0.35)$. The narrow range of the data makes curve-fitting suspect. However, at the higher porosities a "tailing off" appears to be indicated in a fashion similar to that observed in the centrifugal tensile tests. The porosity of o.6 I proved to be about the limiting value for the use of the shear box.

The values for shear strength determined in this manner and reported by de Quervain (1950) are quite similar. His high value is $0.160 \mathrm{~kg} / \mathrm{cm}^{2}$ at a porosity of 0.65 . Unfortunately the data of Roch ( 1966 ) are not directly comparable as he was concerned with the temperature dependence rather than the density dependence of the shear strength.

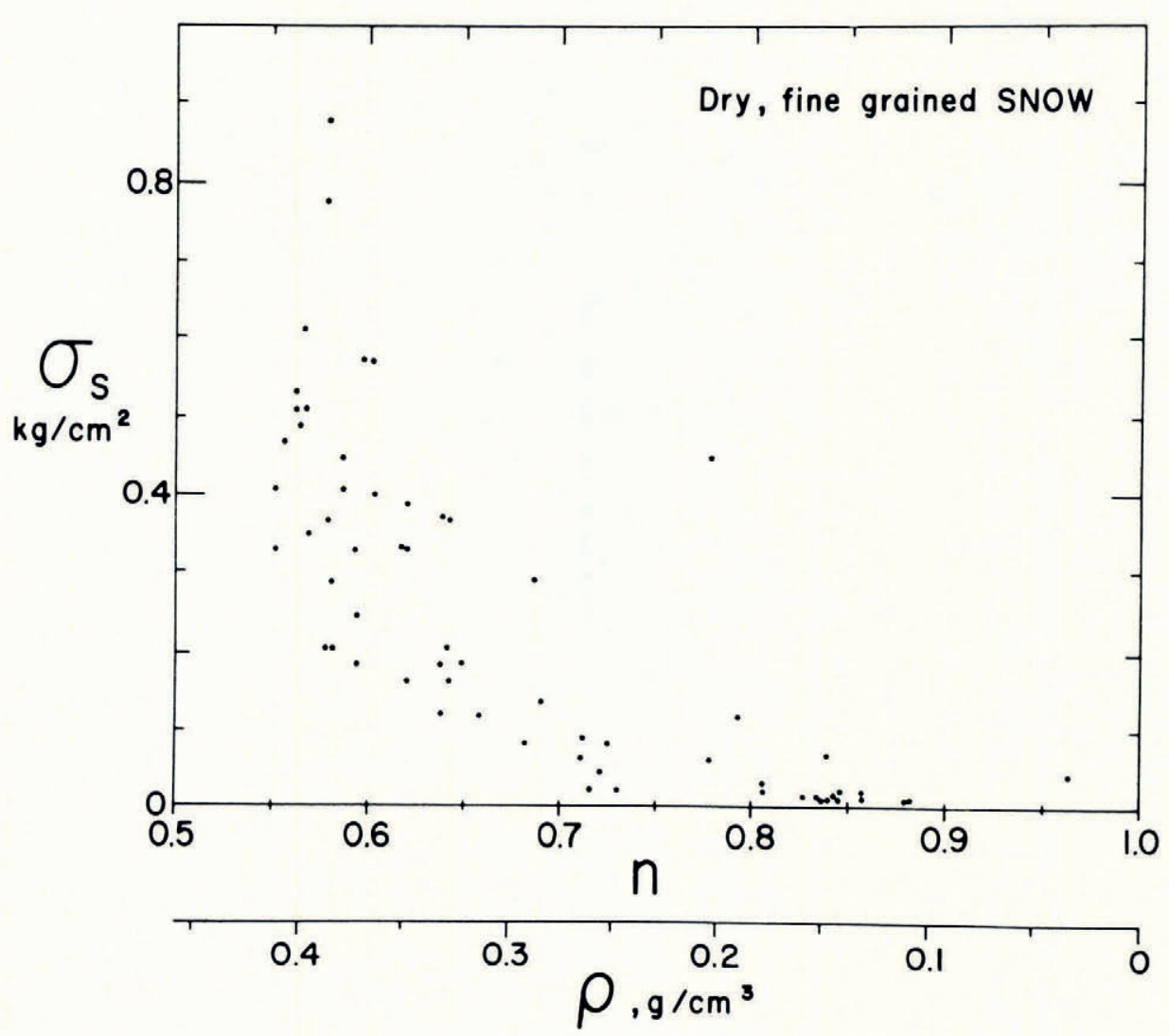

Fig. 7. Shear-box shear strength plotted against porosity (Goose Lake, 1965) 
"In situ" shear vanes. Shear vanes have commonly been used in determining the shear strength of soil in situ. The general technique is well described by Cadling and Odenstad (1950). Recent preliminary studies by Haefeli and Brandenberger (unpublished) performed in conjunction with an E.G.I.G. field party have indicated that a simple shear vane may prove a useful tool in characterizing the vertical variation of shear strength in the snow layers near the surface of the Greenland ice sheet. Their Figure I2 shows an excellent correlation between ram hardness and shear strength. In addition, Diamond and Hansen ( I956) and Rula (I96o) showed that reasonable correlations could be obtained between vane shear strengths and several other snow parameters. The prospect of successfully utilizing the shear vane is particularly attractive as the apparatus is both simple and portable.

Several different types of shear vanes were used on this project. During the 1964 field season, the general dimensions of the vane were based on the design of Haefeli and Brandenberger (unpublished). Both $3 \mathrm{~cm} \times 3 \mathrm{~cm}$ (large) and I $\mathrm{cm} \times 3 \mathrm{~cm}$ (small) vanes were used (Fig. $8 \mathrm{a}, \mathrm{b})$. The height of the vane was deliberately kept small to permit the sampling of thin, homogeneous snow layers. The vanes were inserted to known depths in the snow-pack using extension rods and kept at those depths during a given test by the use of a sliding ring equipped with a set screw which could be located at any point of the rod. This ring then rested on a flat aluminum plate which was set on the surface of the snow and through which the rod passed. The plate was used as the reference level during the tests. For convenience these vanes will be referred to as either the large or small E.G.I.G. shear vanes in this paper.

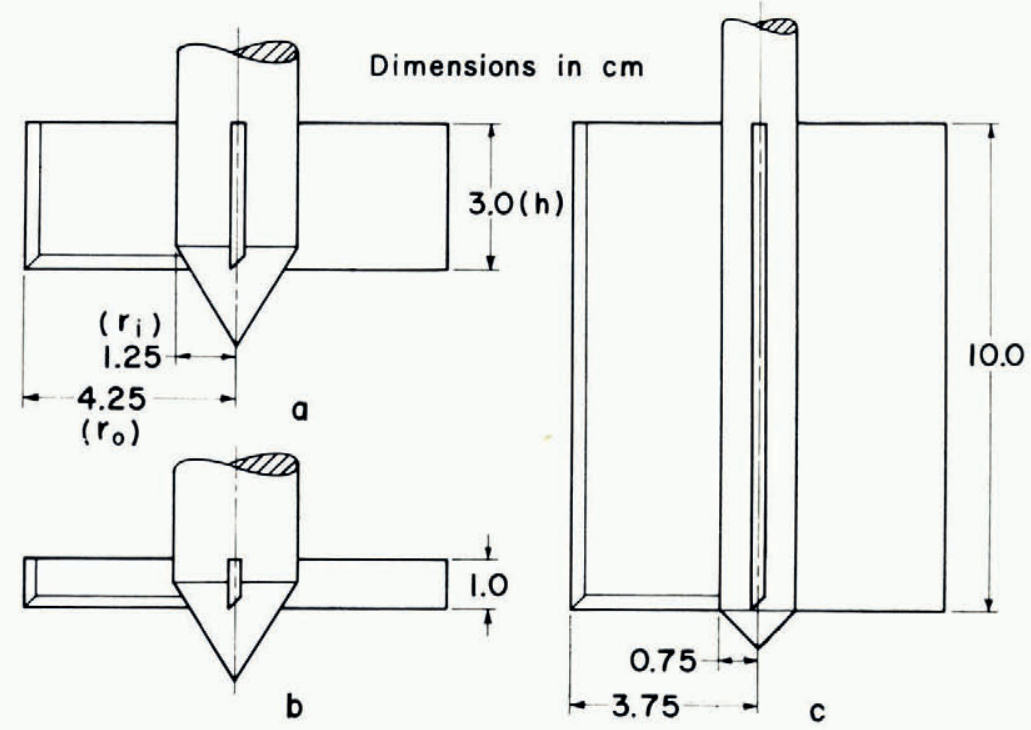

Fig. 8. Schematic diagram of shear vanes

During the 1965 and 1966 field seasons a larger shear vane $(3 \mathrm{~cm} \times 10 \mathrm{~cm})$, similar to those used in soils, was used (Fig. 8c). The vane was on the end of a short rod and was inserted horizontally into the walls of the snow pits. The use of pits allows one to avoid such disturbing influences as ice lenses and allows accurate depth determinations. This vane will be designated as the large shear vane.

The reduction of shear-vane data is treated theoretically by Cadling and Odenstad and can be reduced to the following equation:

$$
M_{\max }=\sigma_{\mathrm{s}}\left[\left(2 \pi r_{0} h\right) r_{0}+2\left(\pi r_{\mathrm{o}}^{2}-\pi r_{i}^{2}\right)\left(r_{\mathrm{i}}+\frac{2}{3}\left(r_{\mathrm{o}}-r_{\mathrm{i}}\right)\right)\right]
$$


where $M_{\max }$ is the torsional moment at failure read from the maximum deflection of the torque wrench, $\sigma_{\mathrm{s}}$ is the failure shear strength, $r_{\mathrm{o}}$ and $r_{\mathrm{i}}$ are the outer and inner radii of the shear vane (see Fig. 8) and $h$ is the height of the vane. In making these computations the effect of side friction is assumed to be negligible. The rotation rate of the vane, although not accurately controlled, is estimated to be roughly $90 \mathrm{deg} / \mathrm{s}(0.25 \mathrm{~Hz})$. There are undoubtedly considerable problems relating to the precise shape and constancy of the failure plane. Unfortunately no information was obtained on this problem because in these tests failure occurs some distance away from the free face.

E.G.I.G. shear vanes. The E.G.I.G. shear vane is located on the end of a rod with a diameter of $2.5 \mathrm{~cm}$. The ends of the vanes are sharpened to minimize the disturbance of the snow as the vane is inserted. To determine whether the presence of the rod had a serious effect on the results, several tests were made at identical locations in which the vane was both (I) inserted directly into the snow and (2) inserted into a pre-drilled hole $2.5 \mathrm{~cm}$ in diameter. There did not appear to be any significant difference between the results obtained by these different methods for either the large or small vanes. In the light of this, most subsequent tests were conducted without a pre-drilled hole. We feel that these results are inconclusive in indicating whether or not pre-drilling makes an appreciable difference as it is our impression that in the low-density snow encountered at Goose Lake in 1964 , the shear vane would not remain in the pre-drilled hole.

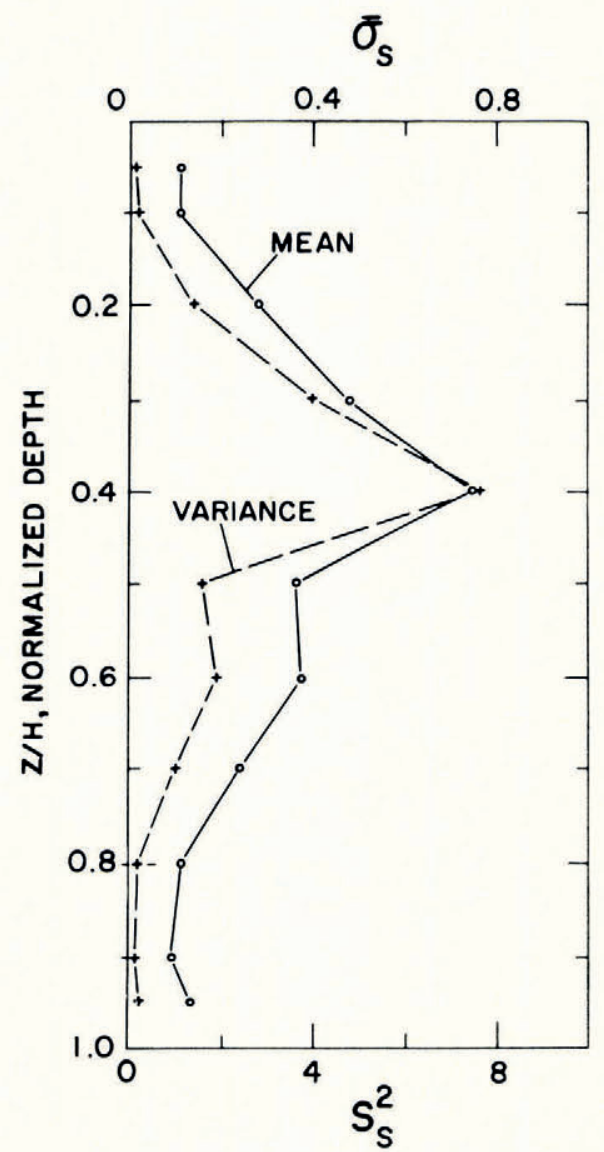

Fig. 9. Variance and mean of shear strengths plotted against normalized depths 
Next the results from comparable snow types using both the larger and smaller E.G.I.G. shear vanes were compared. On the average the larger shear vane gave higher strengths than did the smaller shear vane. This is thought to be a reflection of the fact that the larger vane has a higher probability of encountering stronger layers as it samples a larger area at any given depth indicated on the extension rod. It is, therefore, very desirable to keep shear vane sizes constant when making comparative studies on the strength of snow or any other inhomogeneous material.

In order to obtain some feel for the effects of the lateral variation of snow properties and differences due to different operators several experiments were performed. Between 15 and I 8 May i964, eleven ablation stakes that had been inserted at different locations in the Goose Lake cirque were visited and vertical profiles of shear strength were made. Because the snow depth varied from location to location $\left(2.4^{-3} \mathrm{~m}\right)$ it proved difficult to compare the results from specified levels directly. Therefore, to show the broad features of the vertical strength profile we used a dimensionless thickness $Z_{\mathrm{N}}$ obtained by dividing the depth of a given sample $Z$ by the total thickness of the pack $H$ at that location. This assumes that the thickness of a given snow layer is proportional to the thickness of the snow-pack. We then calculated the mean and the variance of the eleven samples, one from each profile, that were located nearest to the normalized depth of interest. These results are presented in Figure 9 which shows the low average strength of the newer snow at the top of the pack, a stronger layer in the middle portion and the weak depth-hoar layer at the base. The large variances encountered in the middle of the pack are presumably the result of the presence of inhomogeneities such as thin bedded ice lenses. The magnitudes of the variances appear to be directly related to the magnitudes of the average strength values (i.e. on the average snow layers with a higher strength also show a greater scatter). This can be readily seen in Figure ro, which shows the mean shear strength plotted against the associated standard deviation at that depth. The relationship is linear, giving a constant coefficient of variation $\left(S_{\mathrm{s}} / \bar{\sigma}_{\mathrm{s}}\right)$.

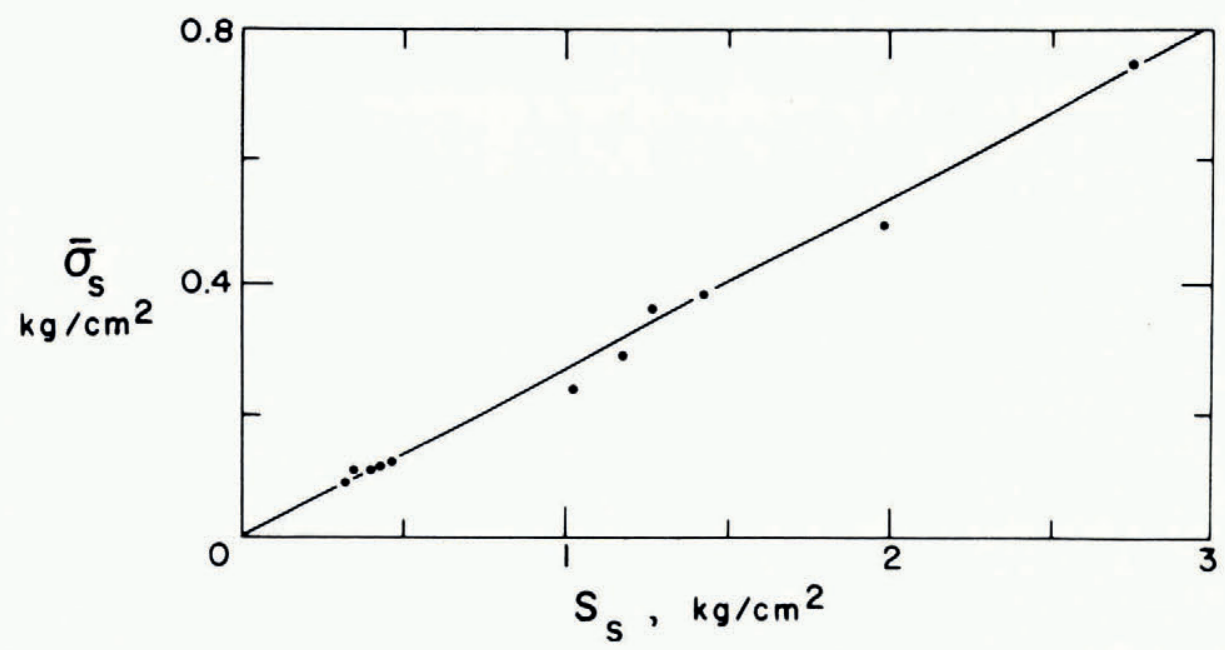

Fig. Io. Mean shear strength plotted against standard deviation of shear strength values

In order to assess the differences in the strength values due to differences in locations and operators, a $30 \mathrm{~m} \times 30 \mathrm{~m}$ grid was laid out. Locations on this grid were then established using a random number table and two operators determined two replicate shear profiles at each location. The sample size is admittedly small; however, it was thought best to complete these measurements in a short period of time to eliminate, as much as possible, variation due to 
time changes in the snow. Shear-strength values were taken at $20 \mathrm{~cm}$ intervals starting at a depth of $10 \mathrm{~cm}$ and terminating at $190 \mathrm{~cm}$. These profiles do not include measurements made in depth hoar.

The results from the sampling grid were analyzed for a given level using a three-level random nested analysis of variance (AOV) model.

$$
r_{i j k}=\mu+a_{i}+b_{i j}+c_{i j k}
$$

where $i=\mathrm{I} \ldots I, j=\mathrm{I} \ldots \mathcal{F}$, and $k=\mathrm{I} \ldots K$. This model states that any shear-strength observation $\sigma_{\mathrm{s}}=Y_{i j k}$ is equal to an overall mean $\mu$ plus the deviation of the $i$ th location mean from overall mean, plus the deviation of the $j$ th operator mean from the location mean, plus the deviation of $k$ th replicate from the operator mean (Krumbein and Graybill, [ 1966 ]). In our specific case $I=6, \mathcal{J}=2$ and $K=2$. Because the standard deviation was shown to be directly proportional to the mean we used a logarithmic transformation on the data to stabilize

Table I. Hypotheses Tests and Variance Estimates from the Three-level Nested E.G.I.G. Shear-vane Experiment (Variance Estimates are Presented on an Untransformed Scale)

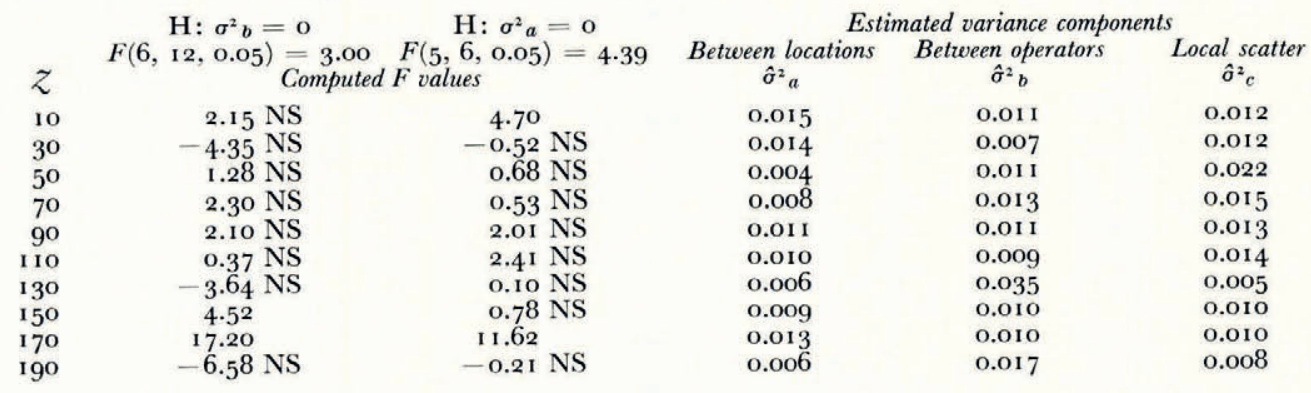

the variance before the AOV calculations were made (Brownlee, ig6o, p. I i4). The results of these calculations are presented in Table I. Here $\hat{\sigma}_{a}^{2}, \hat{\sigma}_{b}^{2}$ and $\hat{\sigma}_{c}^{2}$ represent the estimates of the variance components associated with differences between locations, between operators, and between replicates respectively. Inasmuch as it is reasonable to assume that in this case the variance associated with replication is very small, the values of $\hat{\sigma}_{c}^{2}$ are thought to represent scatter produced by small-scale lateral inhomogeneities in the snow itself. The fact that the maximum value of $\sigma_{c}^{2}$ is found at a depth in the pack where a large number of thin ice lenses occur tends to support this conclusion. Although there is considerable variation in Table I, in most cases the hypotheses that $\sigma_{a}^{2}$ and $\sigma_{b}^{2}$ equal zero are accepted. This indicates that the apparent variation between locations and between operators could (in the sense that the probability is greater than $\mathrm{I}$ in 20 ) be due to local scatter.

Large shear vanes. The experiments conducted with the E.G.I.G. shear vanes suggested that the scatter of data was primarily a function of inhomogeneities in the snow-pack. In order to counteract these effects it was decided (I) to use an even larger shear vane which would, to some extent, average the strength values over a larger volume of snow and (2) to insert the vane horizontally into the pit wall making it possible to locate the sample precisely and to make visual comparisons with the stratigraphic description. This larger vane was used throughout the field seasons of 1965 and 1966 .

The shear strengths of the snow at Goose Lake in 1965 are plotted against porosity in Figure i i. The data show remarkably little scatter when the values for depth hoar are considered separately. This good relationship is thought to be in part due to improved measurement with the large shear vane and in part a testimony to the relative homogeneity of the snow-pack that year. The range of porosities and strengths makes it possible to fit the data with the expression used earlier for the tensile-strength data. In this case $\sigma_{\mathrm{i}}$ for shear is found 


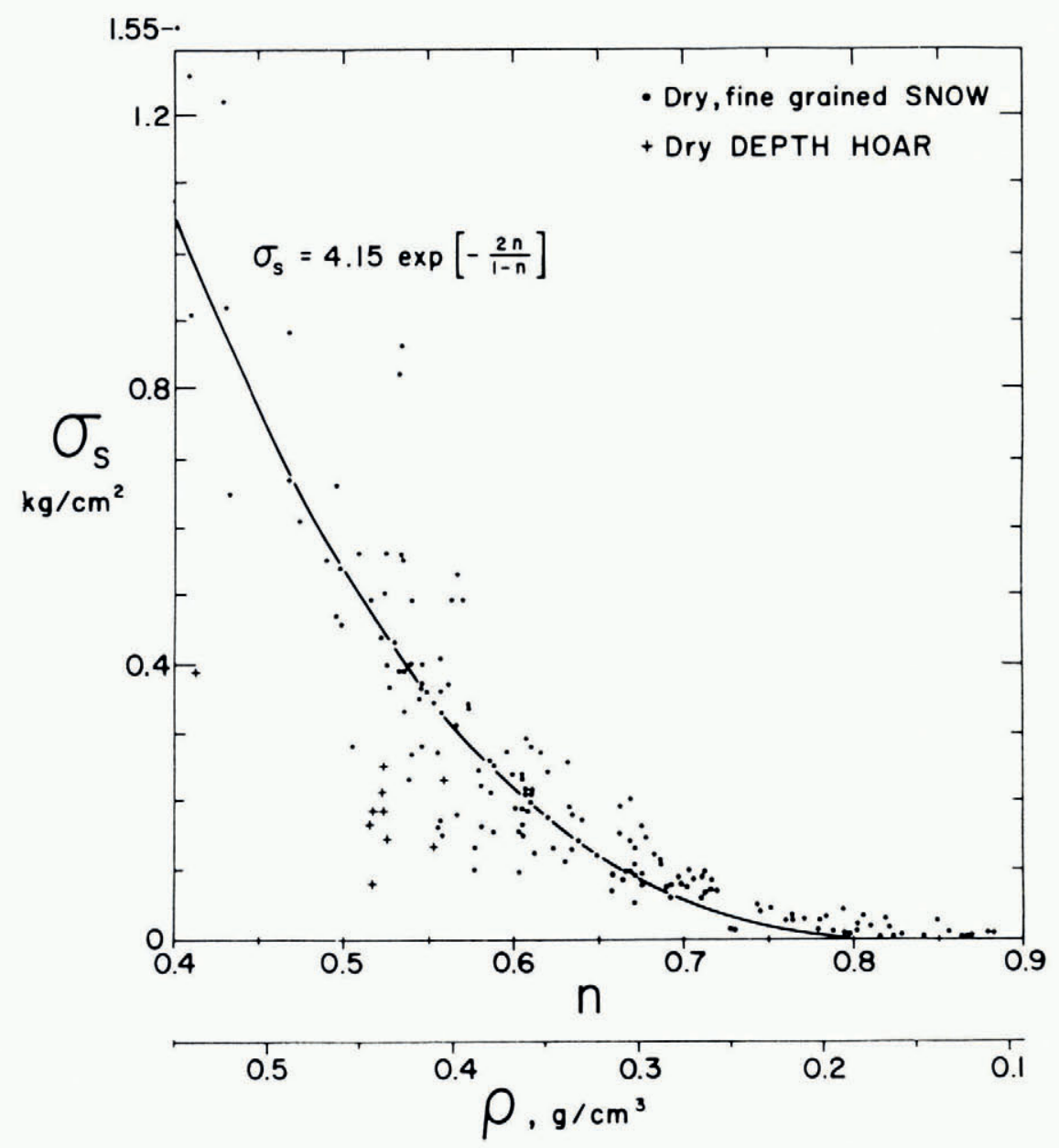

Fig. II. Large shear-vane strength plotted against porosity

to be equal to $4.15 \mathrm{~kg} / \mathrm{cm}^{2}$ when a least-squares analysis is conducted. The correlation coefficient is 0.892 .

Figure 12 shows a plot of shear strengths obtained using the shear vane versus shear strengths obtained using the shear box. As the analysis of shear-box data is straightforward, this close agreement suggests that some confidence can be placed in the shear vane results.

It has already been established that a functional relationship exists between ram hardness and porosity (density). It would therefore be expected that a good correlation could be found between ram hardness and shear strength and that this would be linear. Figure 13 shows this correlation for which $r=+0.868$. It should be noted that the Rammsonde measurement is not made at the same point in space as the shear-vane measurement and consequently lateral variations in the snow-pack affect the correlation.

Other results

Figure 14 presents a comparison of shear-vane measurements and centrifugal tensile strengths from identical snows. In general there appears to be an order of magnitude difference, which is somewhat surprising despite the fact that a similar trend had been noted by 


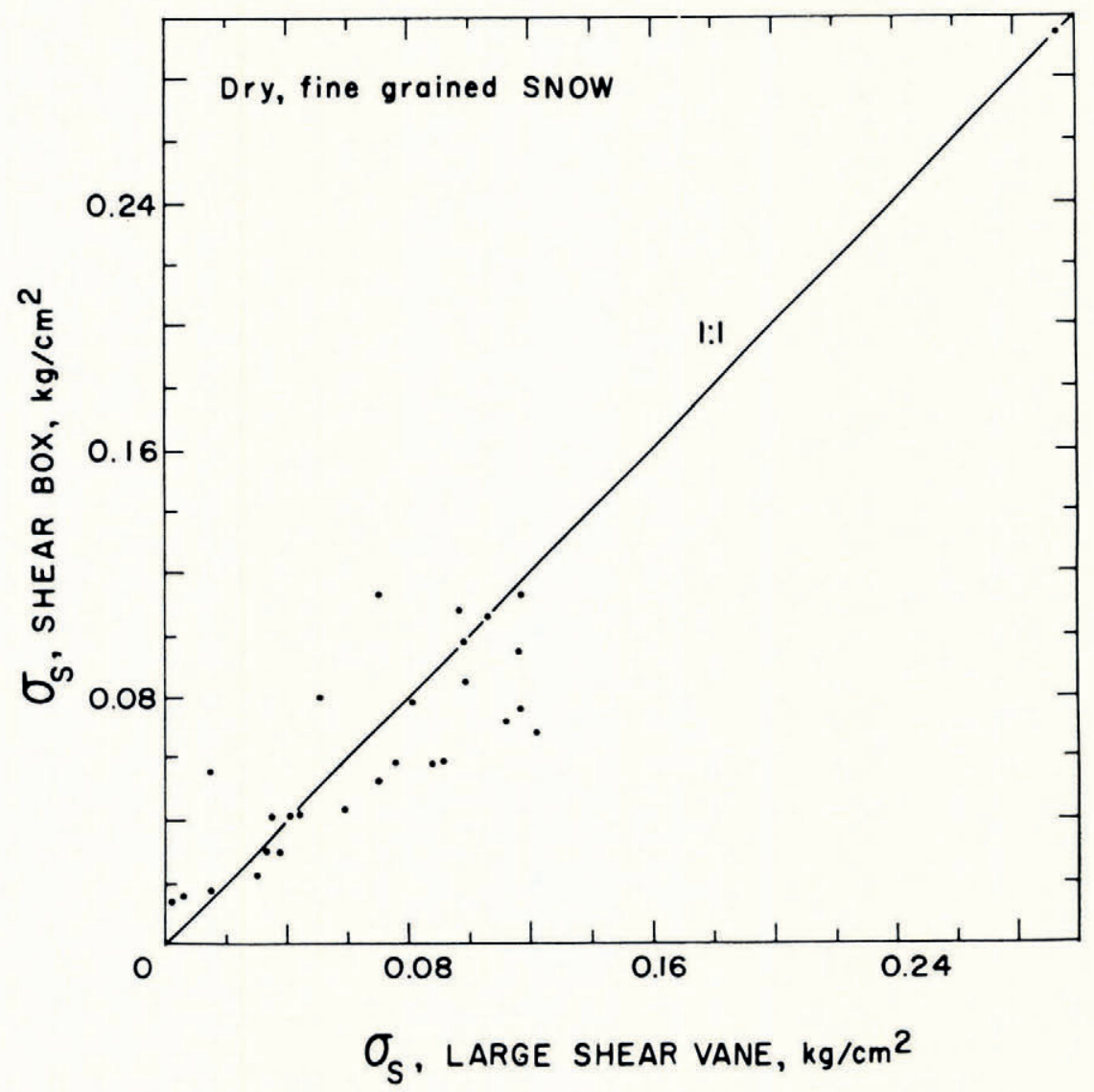

Fig. 12. Shear-vane strength plotted against shear-box strength

Roch (1966). A possible explanation may lie in the test procedures. The loading rate in the shear-vane test exceeded $2 \mathrm{~kg} / \mathrm{cm}^{2} \mathrm{~s}$, whereas the tensile tests loaded the sample at a rate less than $0.5 \mathrm{~kg} / \mathrm{cm}^{2} \mathrm{~s}$. This latter rate may be too slow to produce truly elastic failure.

Figure ${ }_{15}$ shows the change in the value of $\log (C \mathcal{N})$ plotted against porosity where $C \mathcal{N}$ is the hardness of the snow $\left(\mathrm{g} / \mathrm{cm}^{2}\right)$ determined with a Canadian hardness gauge. The changes are quite systematic and within the range of the data may be approximated by the straight line $\log (C \mathcal{N})=6.95-5.88 n$ with a correlation coefficient of -0.903 . This compares quite closely with results from laboratory cone hardness tests conducted by Ager ( 1965 ) who found regression coefficients between 5.5 and 6.5 for various mixtures of dry snow types (exclusive of depth hoar).

\section{Conclusions}

We feel that the results presented in this paper are quite encouraging in that they demonstrate that the mechanical properties of low-density snow can be investigated in the field using simple portable tests. The results show simple systematic relations with appreciably less scatter than would be anticipated from surveying the literature; much of the remaining scatter is undoubtedly due to variations in snow temperature. Several excellent correlations are established between the results of different types of tests which should facilitate the rapid characterization of a given snow-pack. It should be stressed that the systematic relations 


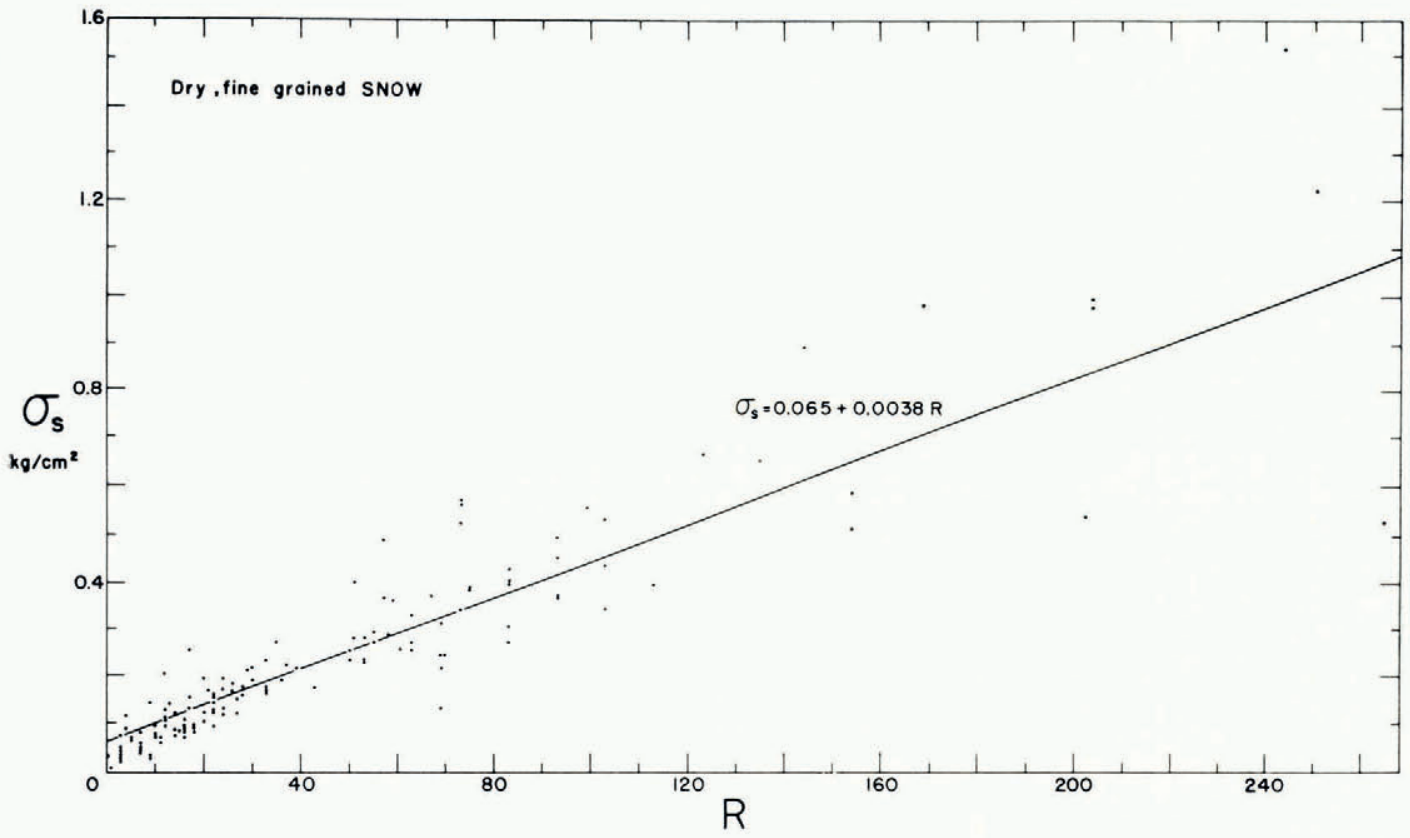

Fig. 13. Shear-vane strength plotted against ram hardness

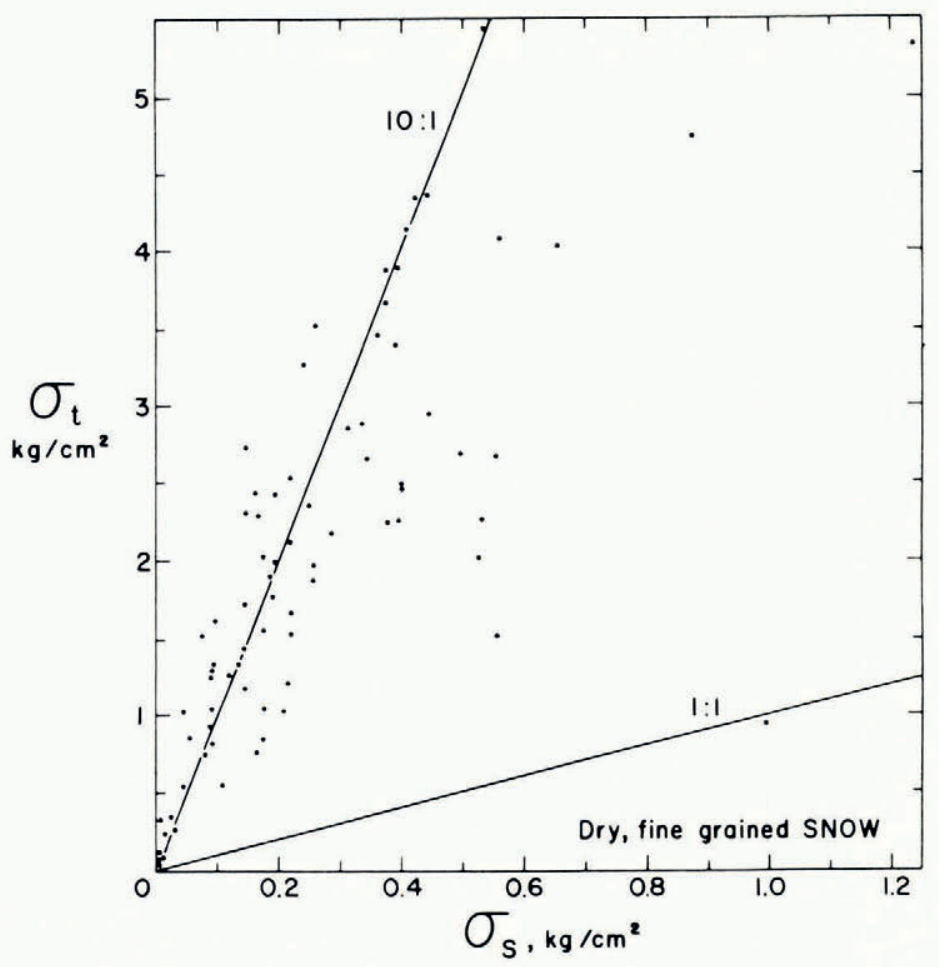

Fig. 14. Centrifugal tensile strength plotted against large shear-vane strength 


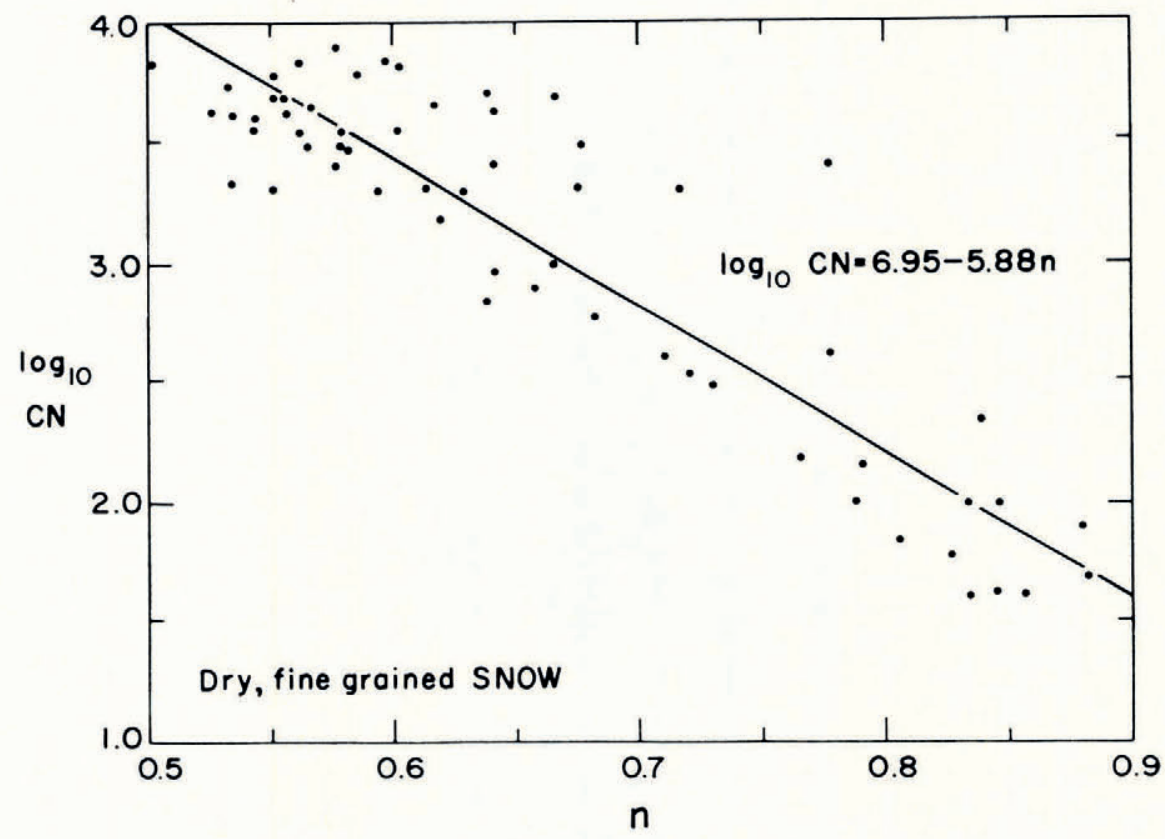

Fig. 15. Logarithm of Canadian hardness plotted against porosity of dry snow

shown in this paper invariably become obscured when different "types" of snow are indiscriminately grouped together. This points to the need for a more thorough study of the structural properties of low-density snow and for an independent means of determining the degree of bonding in a snow-pack. Only when such a technique is available will it be possible to separate the different degrees of constructive metamorphism adequately and to incorporate the important process of depth-hoar formation into an overall strength theory. The need for continued field studies using carefully controlled conditions is obvious.

\section{AcKNowledgements}

The authors would like to acknowledge the efforts of Donald Alford who organized the Goose Lake projects. D. Eberl, G. Thompson, D. Carter, S. Toth and D. Bowles all assisted in the data collection.

MS. received ${ }_{15}$ September ${ }_{1967}$ and in revised form 23 November ${ }_{1967}$

\section{REFERENCES}

Abele, G. 1963. A correlation of unconfined compressive strength and ram hardness of processed snow. U.S. Cold Regions Research and Engineering Laboratory. Technical Report 85.

Ager, B. H. I965. Some tests on the compactibility and hardness after compaction of different types of snow. Journal of Glaciology, Vol. 5, No. 4r, p. 533-46.

Alford, D. L., and Weeks, W. F. 1965. Goose Lake, Montana, 1964: accessibility, field methods and logistics. U.S. Cold Regions Research and Engineering Laboratory. Special Report 77.

Bader, H. 1962. Snow as a material. U.S. Cold Regions Research and Engineering Laboratory. Cold regions science and engineering. Hanover, N.H., Pt. II, Sect. B.

Bader, H., and others. 1939. Der Schnee und seine Metamorphose, von H. Bader, R. Haefeli, E. Bucher, J. Neher, O. Eckel, C. Thams, P. Niggli. Beiträge zur Geologie der Schweiz. Geotechnische Serie. Hydrologie, Lief. 3. [English translation: U.S. Snow, Ice and Permafrost Research Establishment. Translation 14, 1954.]

Bader, H., and others. 195I. Preliminary investigations of some physical properties of snow, by H. Bader, B. L. Hansen, J. H. Joseph and M. A. Sandgren. U.S. Snow, Ice and Permafrost Research Establishment. Report 7. 
Ballard, G. E. H., and Feldt, E. D. 1966. A theoretical consideration of the strength of snow. Journal of Glaciology, Vol. 6, No. 43, p. I $59-70$.

Ballard, G. E. H., and McGaw, R. W. 1966. A theory of snow failure. Union de Géodésie et Géophysique Internationale. Association Internationale d'Hydrologie Scientifique. Commission pour la Neige et la Glace. Division Neige Saisonnière et Avalanches. Symposium international sur les aspects scientifiques des avalanches de neige, 5-10 avril 1965, Davos, Suisse, p. $160-69$.

Benson, C. S. 1962. Stratigraphic studies in the snow and firn of the Greenland ice sheet. U.S. Snow, Ice and Permafrost Research Establishment. Research Report 70.

Bilello, M. A. 1957. A survey of Arctic snow-cover properties as related to climatic conditions. U.S. Snow, Ice and Permafrost Research Establishment. Research Report 39.

Bilello, M. A. 1967. Relationships between climate and regional variations in snow-cover density in North America. (In Oura, H., ed. Physics of snow and ice: international conference on low temperature science. . . . 1966. ...Proceedings, Vol. I, Pt. 2, p. Io I 5-28. [Sapporo], Institute of Low Temperature Science, Hokkaido University.)

Brownlee, K. A. 1960 . Statistical theory and methodology in science and engineering. New York, John Wiley and Sons, Inc.

Bucher, E. 1948. Beitrag zu den theoretischen Grundlagen des Lawinenverbaus. Beiträge zur Geologie der Schweiz. Geotechnische Serie. Hydrologie, Lief. 6. [English translation: U.S. Snow, Ice and Permafrost Research Establishment. Translation $\mathrm{I} 8$, 1956.]

Bull, C. 1956. The use of the rammsonde as an instrument in determining the density of firn. Fournal of Glaciology, Vol. 2, No. 20, p. 71 $4^{-25}$.

Butkovich, T. R. 1956. Strength studies of high-density snow. U.S. Snow, Ice and Permafrost Research Establishment. Research Report 18.

Cadling, L., and Odenstad, S. 1950. The vane borer. Proceedings. Royal Swedish Geotechnical Institute, No. 2.

Diamond, M. 1956. Studies on vehicular trafficability of snow. Pt. I. U.S. Snow, Ice and Permafrost Research Establishment. Report 35 .

Diamond, M., and Hansen, B. L. 1956. Use of a shear vane in snow. U.S. Snow, Ice and Permafrost Research Establishment. Technical Report 40.

Dmitriyeva, N. G. I950. Raschet plotnosti snezhnogo pokrova po meteorologischeskim dannym [Calculation of snow-cover density using meteorological data]. Meteorologiya $i$ Gidrologiya [Meteorology and Hydrology], 1950, No. 2, p. 39-44. [English translation: U.S. Snow, Ice and Permafrost Research Establishment. Translation 24.]

Formozov, A. N. 1946. Snezhnyy pokrov kak faktor sredy, yego znacheniye v zhizni mlekopitayushchikh i ptits SSSR [Snow cover as an environmental factor, its significance in the lives of mammals and birds of the U.S.S.R.]. Moscow, Izdatel'stvo Moskovskogo Obshchestva Ispytateley Prirody [Publishing House of the Moscow Society of Naturalists]. [English translation: Boreal Institute, [University of Alberta]. Occasional Publication No. 1, 1964.]

Gold, L. W. 1958. Changes in a shallow snow cover subject to a temperate climate. fournal of Glaciology, Vol. 3 , No. 23, p. 218-22.

Haefeli, R., and Brandenberger, F. Unpublished. Messungen und Versuche in situ. 3.1. Ramm- und Drehwiderstände. [Mimeographed report headed "EGIG. Faszikel Rheologie, Kapitel 3", produced in 1964.]

Ishihara, K., and Fukui, A. I955. Nihon ni okeru setsuryō chōsa jirei [Examples of snow survey in Japan] Seppyō no Kenkyū [Researches on Snow and Ice], No. 2, p. 203-36.

Judson, A. 1965. The weather and climate of a high mountain pass in the Colorado Rockies. U.S. Forest Service. Rocky Mountain Forest and Range Experiment Station. Research Paper RM-16.

Klein, G. J. 1949. Canadian survey of physical characteristics of snow-covers. Geografiska Annaler, Arg. 3 I, Ht. I-4, p. 106-24.

Krumbein, W. C., and Graybill, F. A. [1966.] An introduction to statistical models in geology. New York, McGrawHill.

Mellor, M. 1964. Properties of snow. U.S. Cold Regions Research and Engineering Laboratory. Cold regions science and engineering. Hanover, N. H., Pt. III, Sect. A

Mellor, M., and Smith, J. H. 1966. Strength studies on snow. Union de Géodésie et Géophysique Internationale. Association Internationale d'Hydrologie Scientifique. Commission pour la Neige et la Glace. Division Neige Saisonnière et Avalanches. Symposium international sur les aspects scientifiques des avalanches de neige, 5-10 avril 1965, Davos, Suisse, p. $\mathrm{IOO}^{-13}$.

Quervain, M. de. 1950. Die Festigkeitseigenschaften der Schneedecke und ihre Messung. Geofisica Pura e Applicata, Vol. 18, p. 1 79-91. [English translation: U.S. Snow, Ice and Permafrost Research Establishment. Translation 9, I951.]

Ramseier, R. O. 1963. Some physical and mechanical properties of polar snow. Fournal of Glaciology, Vol. 4, No. 36 , p. $753-69$

Rikhter, G. D. 1945 . Snezhnyy pokrov, yego formirovaniye i svoystva [Snow cover, its formation and properties]. Moscow, Leningrad, Izdatel'stvo Akademii Nauk SSSR [Publishing House of the Academy of Sciences of the U.S.S.R.]. [English translation: U.S. Snow, Ice and Permafrost Research Establishment. Translation 6, 1954.]

Roch, A. 1966. Les variations de la résistance de la neige. Union de Géodésie et Géophysique Internationale. Association Internationale d'Hydrologie Scientifique. Commission pour la Neige et la Glace. Division Neige Saisonnière et Avalanches. Symposium international sur les aspects scientifiques des avalanches de neige, $5^{-10}$ avril 1965 , Davos, Suisse. p. 86-99.

Rula, A. A. 1960. Trafficability of snow, Greenland studies, 1955 and 1957. U.S. Army Engineer Waterways Experiment Station. Technical Memorandum No. 3-414, Report 3.

Seligman, G. 1936. Snow structure and ski fields. Edinburgh, R. and R. Clark, Ltd.

Williams, G. P., and Gold, L. W. 1958. Snow density and climate. Transactions of the Engineering Institute of Canada, Vol. 2, No. 2, p. 91-94.

Yosida, Z., and others. 1955-58. Physical studies on deposited snow. I-IV. By Z. Yosida [and six others]. Contributions from the Institute of Low Temperature Science, No. 7, 1955, p. 19-74; No. 9, 1956, p. I-81; No. I 1, 1957, p. I-41; No. I 3 , 1958, p. 55-100. 